\title{
Dilemma of the Orthopedic Surgeon - What kind of Graft should we use for ACL Reconstruction?
}

\author{
Károly Pap* \\ Department of Orthopedics and Traumatology, Semmelweis University, Hungary
}

Submission: January 24, 2018; Published: February 02, 2018

*Corresponding author: Károly Pap, Department of Orthopedics and Traumatology, Uzsoki Hospital, Semmelweis University, Uzsoki Street 29-41, 1145 Budapest, Hungary, Tel: +36-70-450-4903; Email: drpapster@gmail.com

\section{Introduction}

ACL reconstruction is a widely used surgical technique It is a regular question which kind of graft should we use? Are Autoor allograft tendons better. There is no simple answer to this question. We have to focus on our patient's needs and consider the level of the preinjury activity/sport level (professional high level athlete or just regularly doing exercises), the time that our patient can spend on the rehabilitation and the time period till our patient can return to sport. If we focus on the problem from this aspect we have to keep in mind the pros and contras of both types of grafts.

If we choose autografts, we obtain a safe graft without any foreign infectious agents. Because it is fresh, most of the fibro- and tendocites will survive and the incorporation will be faster than with allograft. However, every autograft has several potential limitations such as donor site morbidities, graft strengths and measure problems. The demand for ACL allografts has increased in the last decade [1], and postoperative results are promising. It is visible in the increase of allografts use from $2 \%$ (between 1986-1996) to $14 \%$ (between1996-2001), and it further increased around 2007 as its number reached 20\%-30\% in the US [2]. We certainly do not have to struggle with the problems of the donor site, have to face with other challenges. However, there are risk factors associated with the use of allografts, most notably disease transmission - both bacterial and viral, such as human immunodeficiency virus (HIV) and hepatitis [3] - and in some cases fatal septic complications could be observed [4].

The rises in the number of ACL reconstructions and the increasing use of allografts in such repairs have driven the need for an effective sterilization method that preserves the biomechanical integrity of the allograft [1]. Several efforts were made such as antibiotic soaks or washing of tendons in ethanol solutions among others [5]. The penetration of these liquids into the graft tissue was questionable; the ethylene oxide caused chronic synovitis, delayed incorporation or even dissolution of the grafts [5]. Electron beam irradiation was also a promising technique, but its effect is questionable. E-beam was once reported to severely damage the biomechanical properties of the tendons [6], but its damaging effect on tendons is less than that of gamma irradiation [2]. One of the most accepted procedures to minimize the risk of disease transmission by allograft tissue is gamma irradiation. The pathogen inactivation is dose dependent. Greaves et al. [7] found that lower doses of gamma irradiation (10-15 kGy) had only a bactericide effect.

For complete virucidal sterilization, a radiation dosage of $30-50 \mathrm{kGy}$ is required [8]. This method damages the structure of the tendons and decreases their biomechanical properties [5]. Firstly, gamma rays split the polypeptide chains of collagen fibers in a direct manner [9]. Secondly, gamma rays indirectly lead to the radiolysis of water molecules and the consequent release of free radicals which injure the collagen [10]. There is still no consensus on the effect of the gamma irradiation on tendon grafts. Hangody et al. [11] found that we cannot handle all tendon graft in a same manner. The results of this study indicate that different types of tendons react differently to gamma irradiation. Achilles and quadriceps grafts were the most sensitive to gamma irradiation. It seemed that the vulnerability to irradiation of the anterior tibial and slightly of the long peroneal tendons were less than that of the Achilles and quadriceps tendons.

Two systematic reviews found no significant differences between bone-tendon-bone allograft versus autografts for ACL reconstruction $[12,13]$. Almost similar results were found by Cvetnovich et al. [14]. They carried out a meta-analysis comparing the clinical outcomes of patients undergoing ACL reconstruction with hamstring autografts and those undergoing ACL reconstruction with soft-tissue allograft (tibialis anterior, Achilles without bone blocks, irradiated and fresh frozen hamstrings). The comparison of functional outcome, reoperations, septic complications and arthrofibrosis showed no significant differences. But the incorporation of the allografts is slower than the auto grafts. This results in a longer rehabilitation time.

Surgeons are therefore faced with a dilemma when planning an ACL reconstruction. Which type of graft should be used, allograft or autograft? In my opinion in clinical cases where the 
length of rehabilitation is crucial an autograft should be used. All factors have to be taken into consideration (biomechanical properties, donor site morbidity, transmission of diseases, rehabilitation and incorporation time etc.) and discussed with our patient to match their demands.

\section{References}

1. Jung HJ, Vangipuram G, Fisher MB, Yang G, Hsu S, et al. (2011) The effects of multiple freeze-thaw cycles on the biomechanical properties of the human bone-patellar tendon- bone allograft. J Orthop Res 29(8): 1193-1198.

2. Hoburg A, KeshalfS, Schmidt T, Smith M, Gohs U, et al. (2015) High-dose electron beam sterilization of soft tissue grafts maintains significantly improved biomechanical properties compared to standard gamma treatment. Cell Tissue Bank 16(2): 219-226.

3. Yanke A B, Bell R, Lee A, Kang RW, Mather RC, et al. (2013) The biomechanical effects of 1.0 to $1.2 \mathrm{Mrad}$ of gamma irradiation on human bone-patellar tendon- bone allografts. Am J Sports Med 41(4): 835-840.

4. Kainer MA, Linden JV, Whaley DN, Holmes HT, Jarvis WR, et al (2004) Closridium infections associated with musculosceletal-tissue allografts. N Engl J Med 350(25): 2564-2571.

5. Scheffler SU, Scherler J, Pruss A, von Versen R, Weiler A (2005) Biomechanical comparison of human bone-patellar tendon- bone grafts after sterilization with peracetic acid ethanol. Cell Tissue Bank 6(2): 109-115.

6. Schmidt T, Hoburg A, Broziat C, Smith MD, Gohs U, et al. (2012) Sterilization with electron beam irradiation influences the biomechanical properties and the early remodeling of tendon allografts for reconstruction of the anterior cruciate ligament (ACL). Cell Tissue Bank 13(3): 387-400.

\section{This work is licensed under Creative}

Commons Attribution 4.0 License

DOI: 10.19080/OROAJ.2018.10.555786
7. Greaves L, Hecker A, Brown C (2008) The effect of donor age and lowdose gamma irradiationon the initial biomechanical properties of human tibialis tendon allografts. Am J Sports Med 36(7): 1358-1366.

8. Ng K, Wanivenhaus F, Chen T, Abrams VD, Torzilli PA, et al. (2013) Differential cross-linking and radio-protective effects of geninpin on mature bovine and patella tendons. Cell Tissue Bank 14(1): 21-32.

9. Dziedzic-Goclawska A, Kaminski A, Uhrynowska-Tyszkiewicz I, Stachowicz W (2005) Irradiation as a safety procedure in tissue banking. Cell Tissue Bank 6(3): 201-219.

10. Wei W, Liu Y, Yang X et al. (2013) Fraction of 50 kGy electron beam irradiation: Effects on biomechanich of human flexor digitorum superficialis tendons treated with absorbate. J Biomech 46: 658-661.

11. Hangody G, Szebényi G, Abonyi B, Kiss R, Hangody L, et al. (2017) Does a different dose of gamma irradiation have the same effect on five different types of tendon allografts? - a biomechanical study. Int Orthop 41(2): 357-365.

12. Carey JL, Dunn WR, Dahm DL, Zeger SL, Spindler KP (2009) A systematic review of an anterior cruciate ligament reconstruction with autograft compared with autograft. J Bone Joint Surg Am 91(9): 2242-2250.

13. Mariscalo MW, Magnussen RA, Mehta D, Hewrr TE, Flaniga DC, et al. (2014) Autograft versus nonirradiated allograft tissue for anterior cruciate ligament reconstruction: A systematic review. Am J Sports Med 42(2): 492-499.

14. Cvetanovich GL, Mascarenhas R, Saccomanno MF, Verma NN, Cole BJ, et al. (2014) Hamstring Autograft versus soft-tissue allograft in anterior cruciate ligament reconstruction: A systematic review and meta-analysis of randomized controlled trials. Arthroscopy 30(12): 1616-1624.

\section{Your next submission with Juniper Publishers will reach you the below assets}

- Quality Editorial service

- Swift Peer Review

- Reprints availability

- E-prints Service

- Manuscript Podcast for convenient understanding

- Global attainment for your research

- Manuscript accessibility in different formats

( Pdf, E-pub, Full Text, Audio)

- Unceasing customer service

Track the below URL for one-step submission

https://juniperpublishers.com/online-submission.php 